\title{
ANTIBACTERIAL ACTIVITY OF PLANT EXTRACTS AND PHYTOCHEMICALS ON ANTIBIOTIC- RESISTANT BACTERIA
}

\author{
Gislene G. F. Nascimento ${ }^{1 *}$; Juliana Locatelli ${ }^{1}$; Paulo C. Freitas ${ }^{1,2}$; Giuliana L. Silva1 \\ ${ }^{1}$ Faculdade de Ciências da Saúde, Universidade Metodista de Piracicaba, Piracicaba, SP, Brasil. \\ ${ }^{2}$ Faculdade de Ciências Farmacêuticas, Universidade de São Paulo, São Paulo, SP, Brasil
}

Submitted: October 21,1999; Approved: November 14, 2000

\begin{abstract}
The antimicrobial activity of plant extracts and phytochemicals was evaluated with antibiotic susceptible and resistant microorganisms. In addition, the possible synergistic effects when associated with antibiotics were studied. Extracts from the following plants were utilized: Achillea millifolium (yarrow), Caryophyllus aromaticus (clove), Melissa offficinalis (lemon-balm), Ocimun basilucum (basil), Psidium guajava (guava), Punica granatum (pomegranate), Rosmarinus officinalis (rosemary), Salvia officinalis (sage), Syzygyum joabolanum (jambolan) and Thymus vulgaris (thyme). The phytochemicals benzoic acid, cinnamic acid, eugenol and farnesol were also utilized. The highest antimicrobial potentials were observed for the extracts of Caryophyllus aromaticus and Syzygyum joabolanum, which inhibited 64.2 and $57.1 \%$ of the tested microorganisms, respectively, with higher activity against antibiotic-resistant bacteria (83.3\%). Sage and yarrow extracts did not present any antimicrobial activity. Association of antibiotics and plant extracts showed synergistic antibacterial activity against antibiotic-resistant bacteria. The results obtained with Pseudomonas aeruginosa was particularly interesting, since it was inhibited by clove, jambolan, pomegranate and thyme extracts. This inhibition was observed with the individual extracts and when they were used in lower concentrations with ineffective antibiotics.
\end{abstract}

Key words: plant extracts activity; medicinal plants; antimicrobial activity

\section{INTRODUCTION}

Even though pharmacological industries have produced a number of new antibiotics in the last three decades, resistance to these drugs by microorganisms has increased. In general, bacteria have the genetic ability to transmit and acquire resistance to drugs, which are utilized as therapeutic agents (12). Such a fact is cause for concern, because of the number of patients in hospitals who have suppressed immunity, and due to new bacterial strains, which are multi-resistant. Consequently, new infections can occur in hospitals resulting in high mortality.

From 1980 to 1990, Montelli and Levy (27) documented a high incidence of resistant microorganisms in clinical microbiology in Brazil. This fact has also been verified in other clinics around all over world.
The problem of microbial resistance is growing and the outlook for the use of antimicrobial drugs in the future is still uncertain. Therefore, actions must be taken to reduce this problem, for example, to control the use of antibiotic, develop research to better understand the genetic mechanisms of resistance, and to continue studies to develop new drugs, either synthetic or natural. The ultimate goal is to offer appropriate and efficient antimicrobial drugs to the patient.

For a long period of time, plants have been a valuable source of natural products for maintaining human health, especially in the last decade, with more intensive studies for natural therapies. The use of plant compounds for pharmaceutical purposes has gradually increased in Brazil. According to World Health Organization (31) medicinal plants would be the best source to obtain a variety of drugs. About $80 \%$ of individuals from

\footnotetext{
* Corresponding author. Mailing address: Faculdade de Ciências da Saúde, Universidade Metodista de Piracicaba, Caixa Postal 68, CEP 13400-911, Piracicaba, SP. Fax: (+5519) 433-2909. E-mail: ggfranco@unimep.br
} 
developed countries use traditional medicine, which has compounds derived from medicinal plants. Therefore, such plants should be investigated to better understand their properties, safety and efficiency (14).

The use of plant extracts and phytochemicals, both with known antimicrobial properties, can be of great significance in therapeutic treatments. In the last few years, a number of studies have been conducted in different countries to prove such efficiency $(1,5,18,19,22,35,36)$. Many plants have been used because of their antimicrobial traits, which are due to compounds synthesized in the secondary metabolism of the plant. These products are known by their active substances, for example, the phenolic compounds which are part of the essential oils (20), as well as in tannin (33).

The antimicrobial properties of plants have been investigated by a number of researchers world wide, especially in Latin America. In Argentina, a research tested 122 known plant species used for therapeutic treatments (4). It was documented that among the compounds extracted from these plants, twelve inhibited the growth of Staphylococus aureus, ten inhibited Escherichia coli, and four inhibited Aspergillus niger and also reported that the most potent compound was one extracted from Tabebuia impetiginosa. The antimicrobial properties of compounds obtained from Parthenum argentatum against Candida albicans, Torulopsis, Hansemula, Klebsiella pneumoniae and Pseudomonas aeruginosa was detected $(24,25)$. Work done was observed that the substances extracted from nine known plants in Uruguai did not show any activity against $C$. albicans and Saccharomyces cerevisiae, but inhibited the growth of Bacillus subtilis, E. coli and P. aeruginosa (3).

Many studies have been conducted in Brazil. The inhibitory activity of Vatairea macrocarpa on Klebsiella spp. and $S$. aureus was observed (26) and the inhibitory activity of extracts from Eucaliptus spp. against soil fungi (9). A more detailed study on antimicrobial compounds was done evaluating extracts from 120 plant species from 28 different families (32). It was documented that 81 extracts obtanained from 58 plants were active against $S$. aureus, and five extracts from four other plants inhibited the growth of $P$. aeruginosa. Another study (23) detected the antibacterial and antifungal (C. albicans) activity of essential oils obtained from Croton triangularis leaves. Extracts from Lippia gracilis and Xylopia sericea showed antifungal activity. The investigation of antimicrobial activity as well as cell toxicity of extracts from 30 plant species against five bacteria species and two fungi species was studied (29). It was concluded that ethanol extracts from $70 \%$ of the plants were toxic to cell and only one of the species of Combretum duarteanum showed antimicrobial activity. The toxicity of extracts from Arthemus sativa, which is known to have antimicrobial activity, was also studied (10). The antimicrobial activity from Mikania triangularis, known as "thin leaf guaco", was tested against five genera of bacteria and three genera of yeast, and showed it had activity against Bacillus cereus, E. coli, P. aeruginosa, S. aureus and S. epidermidis (13).

Effects of phytochemical were conducted $(19,20)$ and it was observed the antimicrobial activity of anacardic acid on $S$. aureus, Brevibacterium ammoniagenes, Streptococcus mutans and Propionibacterium acnes. Later, it was tested the bactericidal activity of anacardic acid and totarol on methicillin resistant strains of $S$. aureus (MRSA) and the synergistic effect of these compounds associated with methicillin (28).

Hence, more studies pertaining to the use of plants as therapeutic agents should be emphasized, especially those related to the control of antibiotic resistant microbes. The objective of this research was to evaluate the potential of plant extracts and phytochemicals on standard microorganism strains as well as multi-drug resistant bacteria, which were isolated from hospitals. Moreover, we investigated the synergistic effects of extracts with antimicrobial activity in association with antibiotics against drugs resistant bacteria.

\section{MATERIALS AND METHODS}

\section{Microbial samples}

Fourteen microbial species were analyzed. The bacteria (numbered from 1 to 3 ) were taken from international collections and are sensitive to the antibiotics listed below. The yeast sample (number 5) and the bacteria (numbers 4 to 14) were isolated from local hospitals for previous studies. 1Staphylococcus aureus ATCC 6538; 2- Salmonella choleraesuis ATCC 10708; 3- Pseudomonas aeruginosa ATCC 15442; 4- Bacillus subtilis; 5- Candida albicans; 6Proteus spp.; 7- Klebsiella pneumoniae - resistant to AP; 8K. pneumoniae - resistant to AM, AN, AP, CF, CFO, CFR, CO, CR, CTX, NET, NOR, PP, TB and TT; 9- Shigella spp. - resistant to $\mathrm{AP}, \mathrm{CR}, \mathrm{CF}, \mathrm{CFO}, \mathrm{CRO}$; 10-Proteus spp. - resistant to $\mathrm{AN}$, $\mathrm{AM}, \mathrm{AP}, \mathrm{CF}, \mathrm{CFO}, \mathrm{CO}, \mathrm{CR}, \mathrm{CRO}, \mathrm{CTX}, \mathrm{GN}, \mathrm{KN}, \mathrm{NET}$, NOR, $\mathrm{PP}$, SFT, TB, TT; 11-Pseudomonas aeruginosa - resistant to $\mathrm{AN}, \mathrm{AM}, \mathrm{AP}, \mathrm{CF}, \mathrm{CFO}, \mathrm{CFR}, \mathrm{CO}, \mathrm{CR}, \mathrm{CRO}, \mathrm{CTX}, \mathrm{GN}, \mathrm{KN}$, NET, NOR, PP, SFT, TB, TT; 12- Enterobacter aerogenes resistant to AN, AM, AP, CF, CFO, CO, CR, CRO, CTX, GN, KN, NET, NOR, PP, SFT, TB, TT; 13-Escherichia coli - resistant to AM, AP, CF, CFR, CO, CR, GN, NET, PP, SFT, TB, TT; 14Staphylococcus aureus - resistant to AM, CF, CFO, CFR, CO, EI, GN, KN, MET, NOR, SF, TT.

[AM - Amikacin; AP - Ampicillin; CF - Cephalothin CFR Cefpirome CR - Carbenicillin; CFO - Cefoxitin, CO Chloramphenicol; CRO - Ceftraxone, CTX - Cefotaxime; EI Erytromycin, GN - Gentamicin; KN - Kanamycin; LN Lincomycin, MET - Methicillin; NA - Nalidixic Acid, NET Netilmicin, NOR - Norfloxacin, NT - Nitrofurantoin, PN Penicillin, PP - Piperacillin; RF - Rifampicin, SF - Sulfonamide, SFT - Sulfamethoxazole, TB - Tobramycin, TT - Tetracycline; VC - Vancomycin ]. 


\section{Culture media, antibiotics and phytochemical solutions}

Brain Heart Infusion (as liquid and solid media) and MuellerHinton agar were used. The following antibiotic solutions were prepared prior incorporation into the liquid medium: Chloramphenicol (Carlo Erba) $(500 \mu \mathrm{g} / \mathrm{mL})$; Ampicillin (Honorterápica) $(500 \mu \mathrm{g} / \mathrm{mL})$, and Tetracycline (Bristol) $(500$ $\mu \mathrm{g} / \mathrm{mL}$ ). The phytochemical solutions used were: Benzoic Acid (Sigma) dissolved in water, Cinnamic Acid (Fluka), Eugenol (Sigma), and Farnesol (Dragoco) dissolved in ethanol at 10\% concentration.

\section{Plant extracts}

The methodologies of Harbone (17) and Wagner et al. (37) were used to process the ethanolic extracts (1:1) from the ten plants of interest. Seven of them (basil, clove, lemon balm, rosemary, sage, thyme and yarrow) had essential oils as the main active ingredient, while the other three (guava, jambolan and pomegranate) had high contents of tannin. With the exception of clove, all of the plants with essential oils were cultivated from seeds in the Greenhouse of Medicinal Plants at the Methodist University of Piracicaba, SP, Brazil. The seeds were acquired at Semex, SP, Brazil. Clove was obtained from medicinal plants market of São Paulo city. The selected plants with tannins were obtained in the Horticulture Department at the University of Agriculture "Luiz de Queiroz"/USP, Piracicaba, SP, Brazil.

The following lists the plant of interest, plant parts used for extractions, and compounds obtained.

- Thyme (Thymus vulgaris L., Lamiaceae) - [stripped and dried leaves and flowers]. Chemical constituents: essential oils (mainly thymol and carvacrol), flavonoids, tannins and triterpenes (8).

- Rosemary (Rosmarinus officinalis L., Lamiaceae) - [leaf]. Chemical constituents: flavonoids, phenolic acids (caffeic, chorogenic and rosmarinic) and essencial oils (camphor and cineole) and diterpenes (carnosol) (30)

- Lemon balm (Melissa officinalis L., Lamiaceae) - [leaf]. Chemical constituents: essencial oils (containing citral and citronellal monoterpenes), flavonoids and rosmarinic, caffeic and chlorogenic acids (8).

- Sage (Salvia officinalis L., Lamiaceae) - [leaf]. Chemical constituents: rosmarinic, caffeic, chlorogenic acids; carnosol, flavonoids, essential oils (mainly thuyone and cineole). (30).

- Basil (Ocimum basilicum L., Lamiaceae) - [leaf]. Chemical constituents: essential oils (linalol, estragol and eugenol); tannins and flavonoids (8).

- Yarrow (Achillea millefolium L.,Asteraceae) - [flowerheads]. Chemical constituents: flavonoids, tannins, comarins, proazulene. $(8,11)$.

- Clove (Syzygium aromaticum (L.) Merr. et Perry = Caryophyllus aromaticus L.) - [dried buds]. Chemical constituents: essential oils (eugenol); taninns and flavonoids $(8,15)$.

- Pomegranate (Punica granatum L., Punicaceae) [pericarp]. Chemical constituents: ellagitannins and alkaloids. (36).

- Jambolan (Syzygium cumini, Skeels, Myrtaceae) - [leaf]. Chemical constituents: flavonoids and tannins (7).

- Guava (Psidium guajava L., Myrtaceae) - [leaf]. Chemical constituents: comarins, essencial oils, flavonoids, triterpenes and ellagitannins. (16).

\section{Screening for the antimicrobial potential of the plant extracts and phytochemicals (6)}

The bacteria cultures were grown in Brain Heart Infusion liquid medium at $37^{\circ} \mathrm{C}$. After $6 \mathrm{~h}$ of growth, each microorganism, at a concentration of $10^{6} \mathrm{cells} / \mathrm{mL}$, was inoculated on the surface of Mueller-Hinton agar plates. Subsequently, filter paper discs $(6 \mathrm{~mm}$ in diameter) saturated either with extract or phytochemicals $(50 \mu \mathrm{L})$ were placed on surface of each inoculated plate. To evaluate the efficiency of the methodology, each extract was inserted simultaneously in a hole made $(50 \mu \mathrm{L})$ in new plates. The plates were incubated at $37{ }^{\circ} \mathrm{C}$ for $24 \mathrm{~h}$. After this period, it was possible to observe inhibition zone. Overall, cultured bacteria with halos equal to or greater than $7 \mathrm{~mm}$ were considered susceptible to either the tested extract or phytochemical. DMSO and Tween 80 to $2 \%$ were used to dissolve the extracts in the culture media when necessary. The controls were the solvents used for each extract and the phytochemicals and they showed no inhibitions in preliminary studies.

The extracts and the phytochemicals that showed antimicrobial activity were later tested to determine the Minimal Inhibitory Concentration (MIC) for each bacterial sample. Seven bacterial samples $[P$. aeruginosa $(11), K$. pnemoniae (7, 8), Shigella (9), Proteus (10), S. aureus (14) and E. aerogenes (12)] were grown in nutrient broth for $6 \mathrm{~h}$. After, $100 \mu \mathrm{L}$ of $10^{6}$ cells $/ \mathrm{mL}$ was inoculated in tubes with nutrient broth supplemented with different concentrations (10 - 500 $\mu \mathrm{L}$ ) of the extracts and phytochemicals, respectively. Afterwards $24 \mathrm{~h}$ at $37{ }^{\circ} \mathrm{C}$, the MIC of each sample was determined by measuring the optical density in the spectrophotometer $(620$ $\mathrm{nm}$ ), comparing the sample readout with the was non inoculated nutrient broth.

\section{Evaluation of the synergistic effect of antibiotics and plant extracts or phytochemicals on resistant bacterial samples}

This evaluation was done according to Muroi and Kubo (28). Aliquots of $100 \mu \mathrm{L}$ of resistant bacterial cultures $\left(10^{6}\right.$ cells/ $\mathrm{mL}$ ) grown in $10 \mathrm{~mL}$ of nutrient broth for $6 \mathrm{~h}$ were inoculated in nutrient broth supplemented with the respective antibiotics $(50 \mu \mathrm{g} / \mathrm{mL})$ with different concentrations of plant extracts. The concentration for plant extracts/phytochemicals ranged from 
10 to $500 \mu \mathrm{g} / \mathrm{mL}$, based on MIC values, that had previously been evaluated. Only ampicillin and/or chloramphenicol and/or tetracycline were used at the sub-inhibitory concentration (50 $\mu \mathrm{g} / \mathrm{mL})$. The growth conditions were the same as previously mentioned. After $48 \mathrm{~h}$, the optical density of each sample was documented and compared to those of MIC to verify any synergistic effect among the tested compounds.

\section{RESULTS AND DISCUSSION}

\section{Evaluation of the antimicrobial potential of plant extracts and phytochemicals}

The data pertaining to the antimicrobial potential of the plant extracts and phytochemicals are presented in Tables 1 and 2, and Figs. 1 and 2, respectively.

Table 1. Antimicrobial activity caused by plant extracts (hydro-alcoholic fraction) through agar diffusion method.

\begin{tabular}{|c|c|c|c|c|c|c|c|c|c|c|}
\hline microorg. & thyme & rosemary & clove & jambolan & lemonbalm & pomegranate & guava & sage & basil & yarrow \\
\hline 2 & - & - & + & - & + & - & - & - & - & - \\
\hline 4 & - & + & - & - & - & + & - & - & - & - \\
\hline 5 & + & + & + & + & - & - & + & - & - & - \\
\hline 6 & + & - & - & + & - & - & - & - & - & - \\
\hline 8 & - & - & + & - & - & - & - & - & - & - \\
\hline 9 & - & - & + & - & - & - & - & - & - & - \\
\hline 10 & - & - & + & + & - & - & - & - & - & - \\
\hline 11 & + & - & + & + & - & - & - & - & - & - \\
\hline 12 & - & - & - & + & - & - & - & - & - & - \\
\hline 13 & - & - & - & - & - & - & - & - & - & - \\
\hline
\end{tabular}

(+) susceptibility (inhibition zone $\geq 7 \mathrm{~mm}$ )

(- ) absence of susceptibility

(1) Staphylococcus aureus, (2) Salmonella choleraesuis, (3) Pseudomonas aeruginosa, (4) Bacillus subtilis, (5) Candida albicans, (6) Proteus spp, (7) Klebsiella pneumoniae, (8) K. pneumoniae, (9) Shigella spp, (10) Proteus spp, (11) P. aeruginosa, (12) Enterobacter aerogenes, (13) Escherichia coli, (14) S. aureus.

Table 2. Antimicrobial activity caused by phytochemicals through agar diffusion method.

\begin{tabular}{ccccc}
\hline Microorg. & eugenol & farnesol & benzoic acid & cinnamic acid \\
\hline 1 & + & - & - & - \\
2 & + & - & - & - \\
3 & - & - & - & - \\
4 & + & - & - & - \\
5 & + & - & - & - \\
6 & - & - & - & - \\
7 & - & - & - & - \\
8 & - & - & - & - \\
9 & - & - & - & - \\
10 & - & - & - & + \\
12 & - & - & + & + \\
14 & - & - & - & + \\
\end{tabular}

(+) susceptibility (inhibition zone $\geq 7 \mathrm{~mm}$ )

(-) absence of susceptibility 


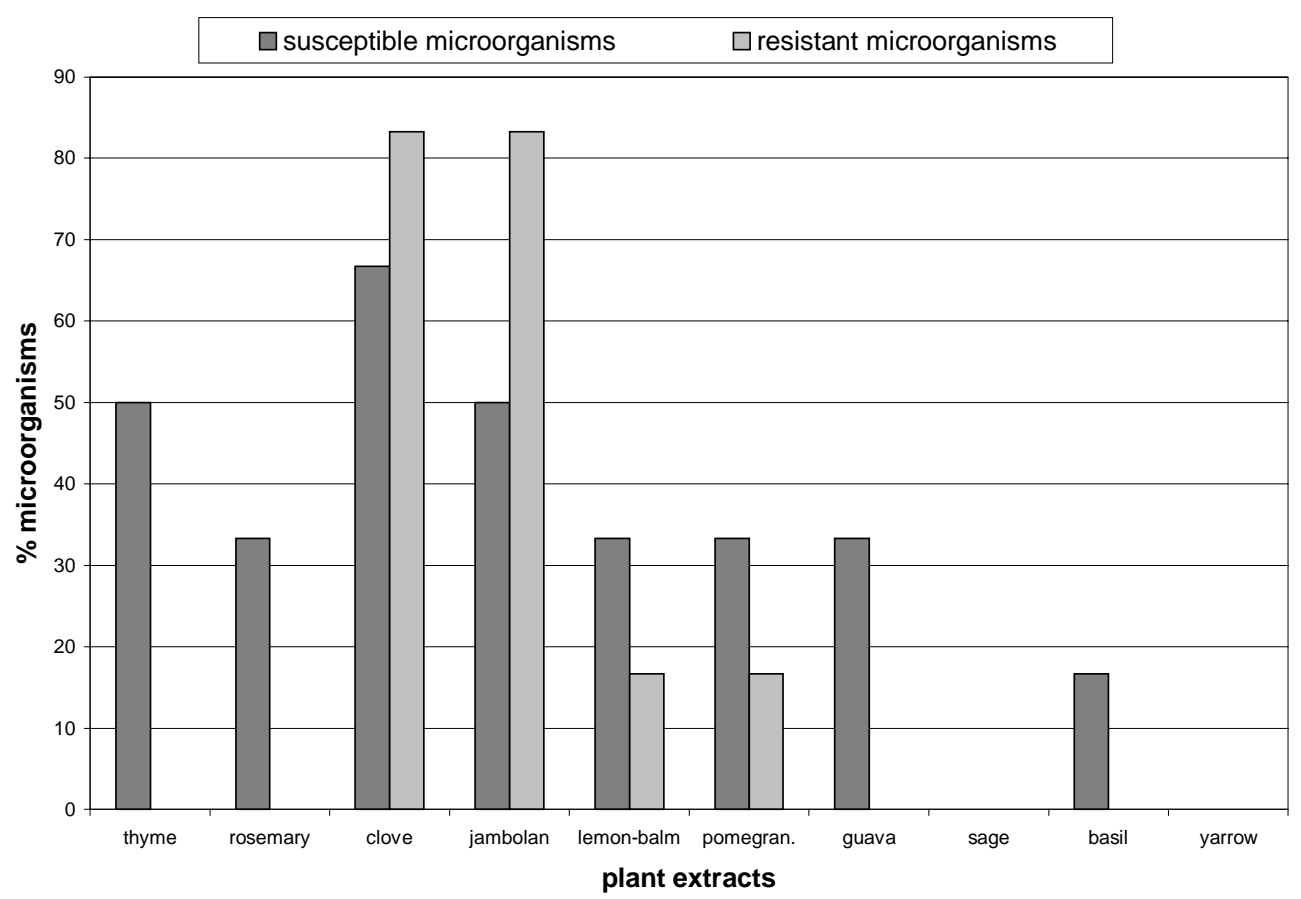

Figure 1 - Antimicrobial activity from plant extracts against susceptible (6) and resistant (8) antibiotic microorganisms

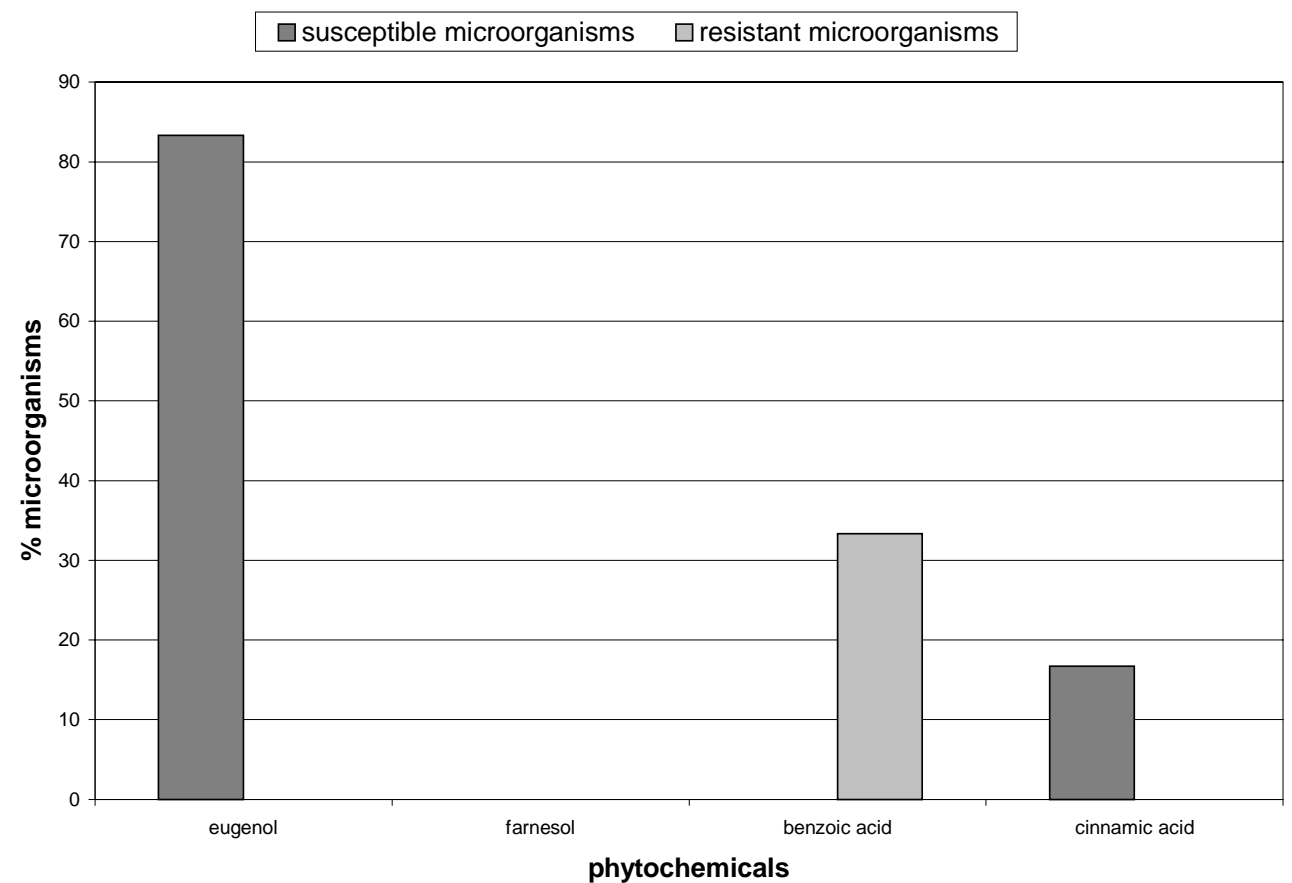

Figure 2 - Antimicrobial activity from phytochemicals against susceptible (6) and resistant (8) antibiotic microorganisms 
The extracts from basil, clove, guava, jambolan, lemon balm, pomegranate, rosemary and thyme presented antimicrobial activity to at least one of the tested microorganisms. The extracts from clove and jambolan presented the highest activities, i. e., they were able to inhibit $9(64.2 \%)$ and 8 (57.1\%) types of microorganisms of interest, respectively. Moreover, they also had the highest activity rate against antibiotic resistant bacteria, which was $83.3 \%$ (Fig, 1). On the other hand, the extracts from sage and yarrow did not show any anti-microbial activity.

One of the microorganism that showed susceptibility to these extracts was $C$. albicans. The susceptibility of this yeast to different plant extracts has been documented in the literature $(3,23,24,29,33)$.

Some of the extracts of phytochemicals tested were active against $B$. subtilis. Such results were not totally unexpected since these bacteria form resting spores and are more resistant to environmental conditions than any other tested bacteria.

The microorganism E.coli, which is already known to be multi-resistant to drugs, was also resistant to the plant extracts tested. It was susceptible only to benzoic acid and cinnamic acid. On the other hand, P. aeruginosa (11), which is also resistant to different antibiotics, had its growth inhibited by the extracts from clove, jambolan, pomegranate and thyme. Such results are very interesting, because this bacterium was isolated from a hospital environment and its control is very difficult by therapeutic means. Studies regarding the mode of action for these compounds in the bacterial cell should be done.

The microorganism susceptibility to different extracts did not correlated with the susceptibility or resistance to a particular antibiotic within the same specie. It was clear that bacteria within the same specie, which are susceptible to drugs, showed the higher susceptibility to extracts than those of resistant species. This fact was evident for $S$. aureus numbers 1 and 14 .

Among the phytochemicals, the eugenol, which is extracted from cloves, showed the highest antimicrobial activity. However, when it was associated with cinnamic acid, no activity against resistant bacteria was observed. On the other hand, the benzoic acid, which presented low activity against the investigated bacteria, was the only one that inhibited the resistant ones, while farnesol did not restrain the growth of any tested bacteria.

The data obtained, through the determination of MIC, from the association of antibiotics with extracts or with phytochemicals to observe any synergistic effect are presented in Table 3 and Fig. 3. The results revealed variability in the inhibitory concentrations of each extract for given bacteria. The extracts from jambolan and clove showed activities in the range (concentrations) from 50 to $500 \mu \mathrm{g} / \mathrm{mL}$, and from 20 to 250 $\mu \mathrm{g} / \mathrm{mL}$, respectively. The lowest variation was observed for eugenol, perhaps due to its purity. Saxena et al. (33) documented a MIC varying from 12.5 to $1,000 \mu \mathrm{g} / \mathrm{mL}$ when testing different concentrations of Rhus glaba extracts on both, Gram-negative and Gram-positive bacteria.

\section{Evaluation of the synergistic effect of antibiotics and plant extracts or phytochemicals on the resistant bacteria samples}

Even though the MIC for seven bacterial samples were determined, only five of them were considered for the synergism experiments (Table 4). This was due to the loss of the resistance for a few antibiotics observed in S. aureus (14) and Shigella spp (9) bacteria, probably because of the loss of plasmids, where the resistance genes are usually located.

Since the majority of bacteria were resistant to many antibiotics, only ampicillin and/or chloramphenicol and/or tetracycline were used in the synergism assays. This was because the resistance to at least one of these drugs was common in all the bacteria tested.

A synergistic effect was observed for P. aeruginosa (11), which is resistant to 19 different antibiotics. This occurred during the association of antibiotics with extracts from clove, jambolan, pomegranate and thyme. The extracts alone from jambolan and thyme in the concentration of $50 \mu \mathrm{g} / \mathrm{mL}$ inhibited the bacterial growth. However, a synergetic effect was observed when $10 \mu \mathrm{g} / \mathrm{mL}$ was combined with each one of the antibiotic

Table 3. Minimal Inhibitory Concentration (MIC) of plant extracts and phytochemicals against antibiotic resistant bacteria.

\begin{tabular}{|c|c|c|c|c|c|c|}
\hline \multirow[t]{2}{*}{ Bacteria } & \multirow[b]{2}{*}{ thyme } & \multicolumn{5}{|c|}{ Plant extracts/phytochemicals (mg/mL) } \\
\hline & & jambolan & lemon-balm & pomegranate & clove & eugenol \\
\hline P. aeruginosa (11) & 70 & 50 & & 70 & 50 & \\
\hline K. pneumoniae (7) & & & 200 & & 100 & 20 \\
\hline K. pneumoniae (8) & & & & & 100 & 10 \\
\hline Shigella spp (9) & & & & & 250 & 10 \\
\hline Proteus spp (10) & & & & & 20 & 10 \\
\hline S. aureus (14) & & 300 & & & & \\
\hline E. aerogenes (12) & 70 & 400 & & & & \\
\hline
\end{tabular}




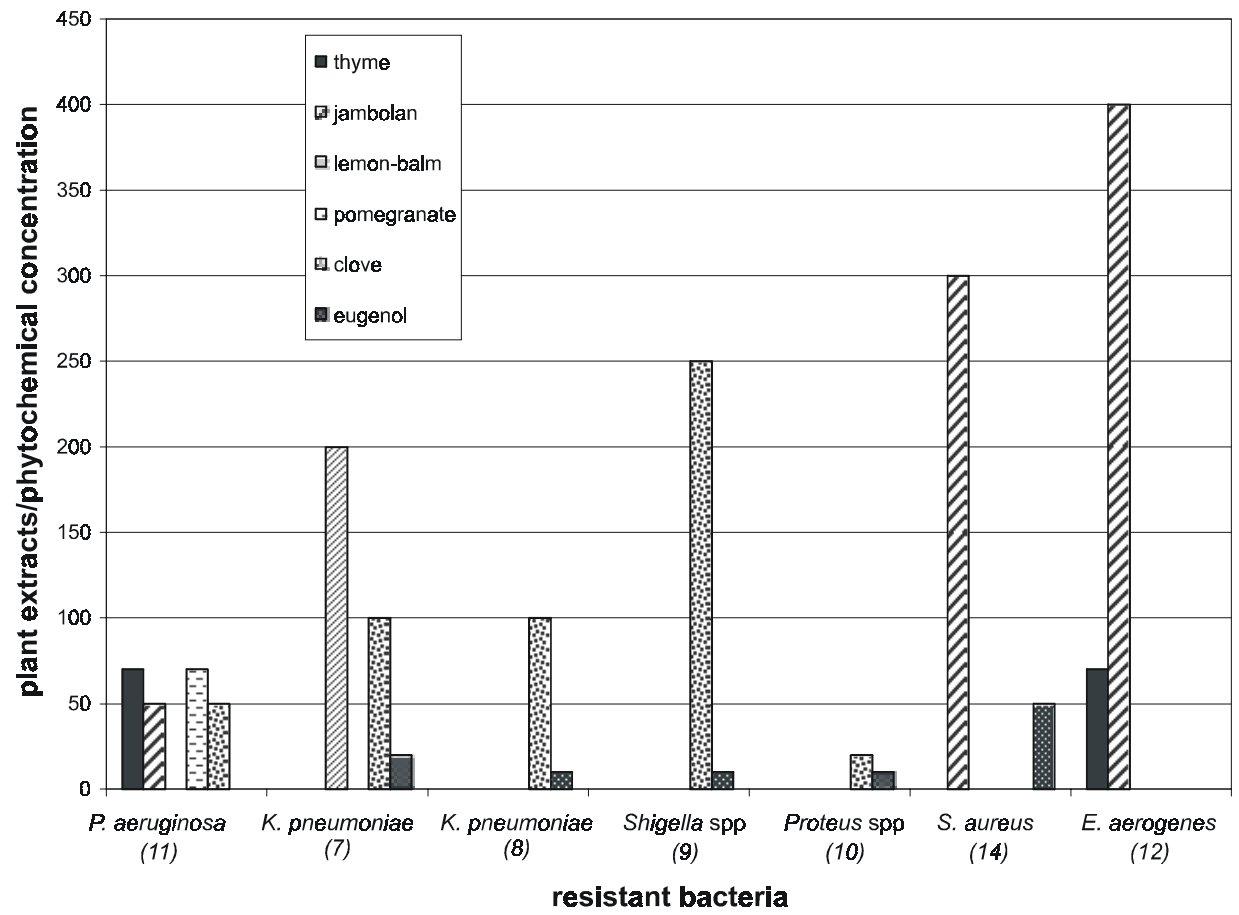

Figure 3 - Minimal Inhibitory Concentration (MIC) of plant extracts/phytochemicals against antibiotic resistant bacteria

tested, even those that did not show any activity by themselves. In the case of pomegranate and clove, the synergetic effect was noted with the extracts in the concentration of 50 and $10 \mu \mathrm{g} /$ $\mathrm{mL}$, respectively. Moreover, this effect was also observed for $K$. pneumoniae (8) when $20 \mu \mathrm{g} / \mathrm{mL}$ of clove extract was combined to ampicillin. Furthermore, the growth of Proteus spp.(10) was inhibited when either clove extract $(10 \mu \mathrm{g} / \mathrm{mL})$ or eugenol $(5 \mu \mathrm{g} / \mathrm{mL})$ was combined to tetracycline. Synergistic effects resulting from the combination of antibiotics with extracts were documented in the literature (28). They studied the association of anacardic acid and totarol with methicillin to inhibit strains of $S$. aureus resistant to methicillin (MRSA).

No synergetic effect was observed when different concentrations of extracts from lemon balm, clove and eugenol were combined with ampicillin to inhibit the growth of $K$. pneumoniae (7) and E. aerogenes (12). Only the association of thyme $(20 \mu \mathrm{g} / \mathrm{mL})$ with ampicillin was able to cause such an effect.

The use of plants to heal diseases, including infectious one, has been extensively applied by people. Data from the literature as well as our results reveal the great potential of plants for therapeutic treatment, in spite of the fact that they have not been completely investigated. Therefore, more studies need to be conducted to search for new compounds. Once extracted, and before being used in new therapeutic treatments, they should have their toxicity tested in vivo. Bioassays $(10,29)$ have demonstrated the toxicity of extracts from different plants.

Therefore, our results revealed the importance of plant extracts when associated with antibiotics, to control resistant bacteria, which are becoming a threat to human health. Furthermore, in a few cases, these plant extracts were active against antibiotic resistant bacteria under very low concentration, thus minimizing the possible toxic effects.

\section{CONCLUSIONS}

Our data express:

1. Plant extracts have great potential as antimicrobial compounds against microorganisms. Thus, they can be used in the treatment of infectious diseases caused by resistant microbes.

2. The synergistic effect from the association of antibiotic with plant extracts against resistant bacteria leads to new choices for the treatment of infectious diseases. This effect enables the use of the respective antibiotic when it is no longer effective by itself during therapeutic treatment. 
Table 4. Effect of the association of plant extracts/phytochemicals and antibiotics on resistant bacteria. (The concentration of the antibiotics was $50 \mathrm{mg} / \mathrm{mL}$ ).

\begin{tabular}{|c|c|c|c|c|c|c|c|c|c|c|c|c|}
\hline \multirow[t]{2}{*}{ Bacteria } & \multirow[t]{2}{*}{ Association } & \multicolumn{11}{|c|}{ Extracts /phytochemicals (mg/mL) } \\
\hline & & 5 & 10 & 20 & 30 & 50 & 70 & 100 & 150 & 200 & 250 & 400 \\
\hline \multirow[t]{16}{*}{ P. aeruginosa (11) } & $\mathrm{J}$ & & - & & - & + & & & & & & \\
\hline & $\mathrm{J}+\mathrm{TT}$ & & + & & + & + & & & & & & \\
\hline & $\mathrm{J}+\mathrm{AP}$ & & + & & + & + & & & & & & \\
\hline & $\mathrm{J}+\mathrm{CO}$ & & + & & + & + & & & & & & \\
\hline & $\mathrm{T}$ & & - & & - & - & + & & & & & \\
\hline & $\mathrm{T}+\mathrm{TT}$ & & + & & + & + & + & & & & & \\
\hline & $\mathrm{T}+\mathrm{AP}$ & & + & & + & + & + & & & & & \\
\hline & $\mathrm{T}+\mathrm{CO}$ & & + & & + & + & + & & & & & \\
\hline & $\mathrm{P}$ & & & - & & - & + & & & & & \\
\hline & $\mathrm{P}+\mathrm{TT}$ & & & - & & + & & & & & & \\
\hline & $\mathrm{P}+\mathrm{AP}$ & & & - & & + & & & & & & \\
\hline & $\mathrm{P}+\mathrm{CO}$ & & & - & & + & & & & & & \\
\hline & $\mathrm{C}$ & & - & - & & + & & & & & & \\
\hline & $\mathrm{C}+\mathrm{TT}$ & & + & + & & + & & & & & & \\
\hline & $\mathrm{C}+\mathrm{AP}$ & & + & + & & + & & & & & & \\
\hline & $\mathrm{C}+\mathrm{CO}$ & & + & + & & + & & & & & & \\
\hline \multirow[t]{6}{*}{ K. pneumoniae (7) } & $\mathrm{L}$ & & & & & - & & - & & + & & \\
\hline & $\mathrm{L}+\mathrm{AP}$ & & & & & - & & - & & + & & \\
\hline & $\mathrm{C}$ & & & & & - & & + & & & & \\
\hline & $\mathrm{C}+\mathrm{AP}$ & & & & & + & & + & & & & \\
\hline & E & & + & + & & & & & & & & \\
\hline & $\mathrm{E}+\mathrm{AP}$ & & + & + & & & & & & & & \\
\hline \multirow[t]{4}{*}{ K. pneumoniae (8) } & $\mathrm{C}$ & & & - & - & - & & + & & & & \\
\hline & $\mathrm{C}+\mathrm{AP}$ & & & + & + & + & & + & & & & \\
\hline & E & - & + & & & & & & & & & \\
\hline & $\mathrm{E}+\mathrm{AP}$ & - & + & & & & & & & & & \\
\hline \multirow[t]{8}{*}{ Proteus (10) } & $\mathrm{C}$ & & - & - & & & & & & & & \\
\hline & $\mathrm{C}+\mathrm{TT}$ & & + & + & & & & & & & & \\
\hline & $\mathrm{C}+\mathrm{AP}$ & & + & + & & & & & & & & \\
\hline & $\mathrm{C}+\mathrm{CO}$ & & + & + & & & & & & & & \\
\hline & E & - & + & & & & & & & & & \\
\hline & $\mathrm{E}+\mathrm{TT}$ & + & + & & & & & & & & & \\
\hline & $\mathrm{E}+\mathrm{AP}$ & + & + & & & & & & & & & \\
\hline & $\mathrm{E}+\mathrm{CO}$ & + & + & & & & & & & & & \\
\hline \multirow[t]{6}{*}{ E. aerogenes (12) } & J & & & & & - & & - & & - & & - \\
\hline & $\mathrm{J}+\mathrm{TT}$ & & & & & - & & - & & - & & - \\
\hline & $\mathrm{J}+\mathrm{AP}$ & & & & & - & & - & & - & & - \\
\hline & $\mathrm{T}$ & & & - & & - & + & & & & & \\
\hline & $\mathrm{T}+\mathrm{TT}$ & & & - & & - & + & & & & & \\
\hline & $\mathrm{T}+\mathrm{AP}$ & & & + & & + & + & & & & & \\
\hline
\end{tabular}

$\mathrm{J}$ - jambolan, T - thyme; $\mathrm{P}$ - pomegranate, C - clove, L - lemon-balm, E - eugenol, TT - tetracycline, AP - ampicillin, CO - cloranfenicol.

(+) susceptibility (-) absence of susceptibility 


\section{ACKNOWLEDGEMENTS}

This study was supported by FAP/UNIMEP and CNPq.

\section{RESUMO}

\section{Atividade de extratos vegetais e fitofármacos sobre bactérias resistentes a antibióticos}

Foi avaliada a atividade antimicrobiana de extratos vegetais e fitofármacos frente a microrganismos sensíveis e resistentes a antibióticos, bem como observado o possível efeito sinérgico da associação entre antibióticos e extratos vegetais. Foram utilizados os extratos de plantas cujo nomes populares são: tomilho, alecrim, cravo-da-Índia, jambolão, erva cidreira, romã, goiaba, sálvia, manjericão e mil-folhas, e ainda os fitofármacos, ácido benzóico, ácido cinâmico, eugenol e farnesol. Na avaliação da atividade antimicrobiana através do método de difusão em agar, foram utilizadas 14 amostras de microrganismos: 1 levedura (Candida albicans), 5 bactérias sensíveis (Staphylococcus aureus, Salmonella choleraesuis, Pseudomonas aeruginosa, Bacillus subtilis, Proteus spp ) e 8 bactérias resistentes a antibióticos isoladas de ambiente hospitalar (2 amostras diferentes de Klebsiella pneumoniae, Shigella spp, Proteus spp, Pseudomonas aeruginosa, Enterobacter aerogenes, Escherichia coli e Staphylococcus aureus. A determinação do CIM e sinergismo foram realizados pela incorporação dos extratos e antibióticos aos meios de culturas liquidos. $\mathrm{O}$ maior potencial antimicrobiano foi verificado para os extratos de cravo e jambolão que inibiram, respectivamente, 64,2 e 57,1\% dos microrganismos, inclusive com maior atividade sobre os microrganismos resistentes a antibióticos (83,3\%). Associação de antibióticos e extratos vegetais ou fitofármacos, sobre bactérias resistentes a antibióticos, mostrou que em alguns casos ocorreu sinergismo, possibilitando que antibióticos já ineficazes apresentassem ação sobre estas bactérias. Os dados obtidos no presente trabalho permitem concluir que estudos mais detalhados sobre o uso terapêutico das plantas devem ser intensificados, principalmente sobre bactérias resistentes a antibióticos, seja na sua ação individual ou em menores concentrações associados com antibióticos.

Palavras-chave: atividade de extratos de plantas; plantas medicinais; atividade antimicrobiana

\section{REFERENCES}

1. Almagboul, A.Z.; Bashir, A.K.; Farouk, A.; Salih A.K.M. Antimicrobial activity of certain Sudanese plants used in folkloric medicine. Screening for antibacterial activity. Fitoterapia 56, 331-337,1985.

2. Almagboul, A.Z.; Bashir, A.K.; Farouk, A.; Salih, A.K.M. Antimicrobial activity of certain Sudanese plants used in folkloric medicine. Screening for antifungal activity. Fitoterapia 59, 393-396, 1988.
3. Alonso-Paz, E.; Cerdeiras, M.P.; Fernandez, J.; Ferreira, F.; Moyna, P.; Soubes, M.; Vazquez, A.; Veros, S.; Zunno, L. Screening of Uruguayan medicinal plants for antimicrobial activity. J. Ethnopharmacology 45, 6770, 1995.

4. Anesini, E.; Perez, C. Screening of plants used in Argentine folk medicine for antimicrobial activity. J. Ethnopharmacol. 39, 119-128, 1993.

5. Artizzu, N.; Bonsignore, L.; Cottiglia, F.; Loy, G. Studies of the diuretic and antimicrobial activity of Cynodon dactylon essencial oil. Fitoterapia 66 , 174-175, 1995

6. Bauer, A.W.; Kirby, E.; Sherris, E.M.; Turk, M. Antibiotic by standarized single disk method. Am. J. Clin. Path. 45, 493-496, 1966.

7. Bhatia, I.S.; Bajaj, K.L. Chemical constituents of the seeds and bark of Syzium cumini. Planta Med. 28, 347-352, 1975.

8. Bisset, N.M. Herbal Drugs and Phytopharmaceuticals. CRC Press, London, 1994, 566 p.

9. Bruna, E.P.; Fernandes, B.; Borges, A.C.; Almeida, J.; Barros, N.F. Effects of Eucalyptus litter extracts on microbial growh. Pesq. Agrop. Bras. 24, 1523 $1528,1989$.

10. Carvalho, V.; Melo, V.M.; Aguiar, A.; Matos, F.S. Toxicity evaluation of medicinal plant extracts by the brine shrump (Arthenus salina Leah) biossay. Ciência e Cultura 40, 1109-1111, 1988.

11. Chandler, R.F.; Hooper, S.N.; Harvey, M.J. Ethnobotany and phytochemistry of yarrow, Achillea millefolium, Compositae. Econ. Bot. 36, 203-223, 1982.

12. Cohen, M.L. Epidemiology of drug resistance: implications for a postantimicrobial era. Science 257, 1050-1055, 1992.

13. Cruz, F.G.; Roque, N.F.; Giesbrecht, A.M.; Davino, S.C. Antibiotic activity of diterpenes from Mikania triangularis. Fitoterapia 67, 189-190, 1996.

14. Ellof, J.N. Which extractant should be used for the screening and isolation of antimicrobial components from plants? J. Ethnopharmacol. 60, 1-6, 1998.

15. Evans, C.W. Trease and Evans' Pharmacognosy. W.B. Sauders, London, $1996,612 \mathrm{p}$

16. Gupta, M.P. 270 Plantas Medicinales Iberoamericanas. CYTED-SECAB, Bogotá, 1995, 617 p.

17. Harbone, J.B. Phytochemical Methods. Chapman \& Hall, London, 1983 , 288 p..

18. Ikram, M.; Inamul, H.. Screening of medicinal plants for antimicrobial activities. Fitoterapia 55, 62-64, 1984.

19. Izzo, A.A.; Di Carlo, G.; Biscardi, D.; Fusco, R.; Mascolo, N.; Borreli, F.; Capasso, F.; Fasulo, M.P.; Autore, G. Biological screening of Italian medicinal plants for antibacterial activity. Phytother. Res. 9, 281-286,1995.

20. Jansen, A.M.; Cheffer, J.J.C.; Svendsen, A.B. Antimicrobial activity of essencial oils: a 1976-1986 literature review. Aspects of test methods. Planta Med.40,395-398, 1987.

21. Kubo, I.; Muroi, H.; Himejima, M. Antimicrobial acitivity of green tea flavor components and their combination effects. J. Agri. Food Chem. 40, 245 248, 1992.

22. Kubo, L.; Muroi, H.; Himejima, M. Structure-antibacterial activity relationships of anacardic acids. J. Agri. Food Chem. 41, 1016-1019, 1993.

23. Lemos, T.L.G.; Monte, F.J.Q.; Matos, F.J.A.; Alencar, J.W.; Craveiro, A.A.; Barbosa, R.C.S.B.; Lima, E.D. Chemical composition and antimicrobial activity of essencial oils from Brazilian plants. Fitoterapia 63, 266-268, 1992.

24. Martinez, M.J.; Vasquez, S.M.; Espinosa-Perez, C.; Dias, M.; HerreraSanchez, M. Antimicrobial properties of argentatine A isolated from Parthenium argentatum. Fitoterapia 65, 371-372, 1994.

25. Martinez, M.J.; Betancourt, J.; Alonso-Gonzalez, N.; Jauregui, A. Screening of some Cuban medicinal plants for antimicrobial activity. J. Ethnopharmacol. 52, 171-174, 1996

26. Matos, F.J.A.; Aguiar, L.M.B.A.; Silva, M.G.A. Chemical constituents and antimicrobial activity of Vatairea macrocarpa Ducke, 1988. Acta Amazonica 18, 351-352, 1988

27. Montelli, A.C.; Levy, C.E.. Sistema COBA - Aspectos relativos aos dados dos laboratórios de referência. Rev. Microbiol. 22, 197-205, 1991.

28. Muroi, H.; Kubo, I.. Antibacterial activity of anacardic acids and totarol, alone and in combination with methicillin, against methicillin-resistant Staphylococcus aureus. J. Appl. Bacteriol. 80, 387-394; 1996.

29. Nascimento, S.C.; Chiappeta, A.; Lima, R.M.O.C. Antimicrobial and cytotoxic activities in plants from Pernambuco, Brazil. Fitoterapia 61, 353-355, 1990.

30. Newall, C.A.; Anderson, L.A.; Phillipson, J.D. Herbal Medicines. A guide for health-care professionals. Royal Pharmaceutical Society of Great Britain, London, 1996, 296 p. 
31. Santos, P.R.V.; Oliveira, A.C.X.; Tomassini, T.C.B. Controle microbiógico de produtos fitoterápicos. Rev. Farm. Bioquím. 31, 35-38, 1995.

32. Santos Filho, D.; Sarti, S.J.; Bastos, J.K.; Leitão Filho, H.F.; Machado, J.O.; Araujo, M.L.C.; Lopes, W.D.; Abreu, J.E. Atividade antibacteriana de extratos vegetais. Rev. Cien. Farm. 12, 39-46, 1990.

33. Saxena, G.; McCutcheon, A.R.; Farmer, S.; Towers, G.H.N.; Hancock, R.E.W. Antimicrobial constituents of Rhus glabra. J. Ethnopharmacol. 42, 95-99, 1994.

34. Scalbert, A. Antimicrobial properties of tanins. Phytochem. 30, 3875-3883, 1991.
35. Shapoval, E.E.S.; Silveira, S.M.; Miranda, M.L.; Alice, C.B.; Henriques, A.T. Evaluation of some pharmacological activities of Eugenia uniflora. J. Ethnopharmacol.44, 136-142, 1994.

36. Sousa, M.; Pinheiro, C.; Matos, M.E.O.; Matos, F.J.; Lacerda, M.I.; Craveiro, A.A. Constituintes Químicos de Plantas Medicinais Brasileiras. Universidade Federal do Ceará, Fortaleza, p. 385-388, 1991.

37. Toda, M.; Okubo, S.; Hiyoshi, R.; Shimamura, T. The bactericidal activity of tea and coffee. Lett. Appl. Microbiol. 8, 123, 1989.

38. Wagner, H.; Blandt, S.; Zgainski, E.M. Plant Drug Analysis. Spring-Verlag, New York, 1984, 320 p. 